\title{
A CONTINUOUS GLUCOSE MONITORING SYSTEM (CGMS) - A PROMISING APPROACH FOR IMPROVING METABOLIC CONTROL IN PERSONS WITH TYPE 1 DIABETES MELLITUS TREATED BY INSULIN PUMPS
}

\author{
Petr Mlčák ${ }^{\mathrm{a}}$, Jana Fialováa ${ }^{\mathrm{a}}$ Kateřina Trnkováa ${ }^{\mathrm{a}}$, Rudolf Chlup ${ }^{\mathrm{a}, \mathrm{b}^{*}}$ \\ ${ }^{a}$ Institute of Physiology, Faculty of Medicine, Palacký University, 77515 Olomouc, Czech Republic \\ ${ }^{b}$ II ${ }^{\text {nd }}$ Department of Medicine, Teaching Hospital \& Faculty of Medicine, Palacký University, I. P. Pavlova 6, 77500 Olomouc, \\ e-mail: rudolf.chlup@fnol.cz
}

Received: May 2, 2004; Accepted: June 25, 2004

Key words: Continuous glucose monitoring/Self-monitoring/Diabetes mellitus/Insulin pump

This pilot study deals with the possibilities of a Continuous Glucose Monitoring System (CGMS, MinimedMedtronic) to optimize insulin substitution. Ten persons with type 1 diabetes mellitus treated by means of an insulin pump entered the study and eight of them completed the protocol. CGMS was introduced for a period of 5 days. The standard dinner ( $60 \mathrm{~g}$ of carbohydrates) and overnight fasting were designed to ensure standard night conditions in all persons in the study while maintaining their usual daily eating routine, physical exercise and assessment of prandial insulin boluses. The only adaptation of basal rates of insulin pump was performed on day 3. Comparison of the mean plasma glucose concentration (0:00-24:00 hrs) between day 2 (before adaptation) and day 4 (following adaptation) was made. An independent comparison of the mean plasma glucose concentration between the night from day 2 till day 3 (22:00-6:00 hrs) and the night from day 4 till day 5 (22:00-6:00 hrs) was performed. The mean plasma glucose investigated by means of CGMS improved in the 24-hour period in 5 out of 8 persons and in the night fasting period (22:00 to $6 \mathrm{hrs}$ ) in 6 out of 8 persons. The CGMS is a useful means for assessment of the effectiveness of basal rate and prandial insulin doses in persons with type 1 diabetes treated by means of an insulin pump. However, further studies are necessary to improve the algorithm for insulin substitution.

\section{INTRODUCTION}

Continuous subcutaneous insulin infusion (CSII) by means of an insulin pump is a sophisticated method for insulin substitution in persons with type 1 diabetes mellitus. Adequate basal rates (BR) and prandial boluses (PB) of the insulin pump are the main assumptions for successful treatment. Routinely, both BR and PB have been applied according to the results of frequent selfmonitoring of plasma glucose (SMPG) performed by means of a glucose meter (5-10 measurements per day). The Continuous Glucose Monitoring System (CGMS), registering 288 glucose concentrations per $24 \mathrm{hrs}$, seems to offer new ways for reaching optimum diabetes control $^{1-9,11,13,15}$.

\section{AIM}

The aim of the present pilot study was to assess whether in persons with type 1 diabetes mellitus treated by means of an insulin pump, the CGMS would enable appropriate adaptation of the BR and/or PB in order to decrease mean plasma glucose (MPG) in the course of 24-hour period and/or in basal (fasting) conditions in the night period.

\section{MATERIALS AND METHODS}

The study was designed and performed from January to April 2003.

Ten persons with type 1 diabetes mellitus (see Table 1) gave their informed consent according to the Declaration of Helsinki and entered the study.

Investigation of glucose concentrations

Glucose concentrations were investigated in interstitial fluid (ISF-glucose) by means of the CGMS (Minimed-Medtronic) and in plasma (P-glucose) by means of a personal glucose meter Optium (Medisense-Abbot). The subcutaneously inserted sensor of the CGMS measured the electrical current that is related to interstitial glucose concentration. The assay method is based on electrochemical detection of glucose through its reaction with glucose oxidase. There is a good correlation between P-glucose (PG) and ISF-glucose ${ }^{14}$. Two CGMS monitors were used in the whole group. Each person was investigated by this means. The CGMS was calibrated every day according to PG values obtained from the glucose meter. Each person performed SMPG at least five times a day. In this study, the ISF-glucose (CGMS) correlated well with P-glucose (Optium) for the whole five-day period of investigation, i. e. not only for 3 days as stated in the literature ${ }^{10}$. 
Table 1. Characteristics of 10 persons with type 1 diabetes mellitus ( $\mathrm{sBP}$ - systolic blood pressure, dBP - diastolic blood pressure).

\begin{tabular}{|c|c|c|c|c|c|c|c|c|c|c|c|}
\hline $\begin{array}{c}\text { Person } \\
\text { No. }\end{array}$ & $\begin{array}{l}\text { Sex } \\
m / f\end{array}$ & $\begin{array}{c}\text { Age } \\
\text { [years] }\end{array}$ & $\begin{array}{l}\text { Height } \\
{[\mathrm{cm}]}\end{array}$ & $\begin{array}{c}\text { Weight } \\
{[\mathrm{kg}]}\end{array}$ & $\begin{array}{c}\text { BMI } \\
{\left[\mathrm{kg} / \mathrm{m}^{2}\right]}\end{array}$ & $\begin{array}{c}\mathrm{sBP} \\
{[\mathrm{mmHg}]}\end{array}$ & $\begin{array}{c}\mathrm{dBP} \\
{[\mathrm{mmHg}]}\end{array}$ & $\begin{array}{c}\mathrm{DM} \\
\text { [years] }\end{array}$ & $\begin{array}{c}\text { CSII } \\
\text { [years] }\end{array}$ & $\begin{array}{l}\text { Insulin } \\
\text { pump }\end{array}$ & $\begin{array}{c}\mathrm{HbA}_{1 \mathrm{C}}{ }^{*} \\
{[\%]}\end{array}$ \\
\hline 1 & $\mathrm{~m}$ & 31 & 180 & 60 & 19 & 100 & 75 & 6 & 4 & MiniMed 507c & 7.2 \\
\hline 2 & $\mathrm{~m}$ & 59 & 163 & 55 & 21 & 115 & 65 & 38 & 5 & MiniMed 508 & 7.2 \\
\hline 3 & $\mathrm{f}$ & 44 & 164 & 60 & 22 & 120 & 85 & 23 & 4 & MiniMed 507c & 6.5 \\
\hline 4 & $\mathrm{~m}$ & 27 & 176 & 79 & 26 & 150 & 100 & 14 & 4 & MiniMed 507c & 6.0 \\
\hline 5 & $\mathrm{f}$ & 37 & 178 & 96 & 30 & 125 & 90 & 4 & 4 & MiniMed 507c & 8.9 \\
\hline 6 & $\mathrm{f}$ & 39 & 164 & 69 & 26 & 110 & 70 & 13 & 3 & MiniMed 507c & 5.8 \\
\hline 7 & $\mathrm{~m}$ & 31 & 177 & 69 & 22 & 125 & 80 & 21 & 0.5 & MiniMed 508 & 5.3 \\
\hline 8 & $\mathrm{f}$ & 61 & 175 & 73 & 24 & 150 & 75 & 9 & 1 & MiniMed 507c & 5.6 \\
\hline 9 & $\mathrm{f}$ & 30 & 176 & 65 & 21 & 120 & 70 & 16 & 10 & H-TRONplus & 5.6 \\
\hline 10 & $\mathrm{f}$ & 22 & 176 & 64 & 21 & 120 & 90 & 7 & 0.5 & MiniMed 508 & 8.7 \\
\hline mean & - & 38 & 173 & 69 & 23 & 124 & 80 & 15 & 3.6 & - & 6.7 \\
\hline $\mathrm{SD}$ & - & 12 & 6.2 & 11 & 3.2 & 15 & 10 & 9.7 & 2.6 & - & 1.2 \\
\hline
\end{tabular}

*Values of $\mathrm{HbA}_{1 \mathrm{c}}$ are expressed according to the IFCC scale (normal range 2.8-4.0\%).

Converssion of $\mathrm{HbA}_{1 \mathrm{c}}$ values: $\mathrm{NGSP}=(0.915 * \mathrm{IFCC})+2.15[\%]$

\section{Study design}

The study design is shown in Fig. 1.

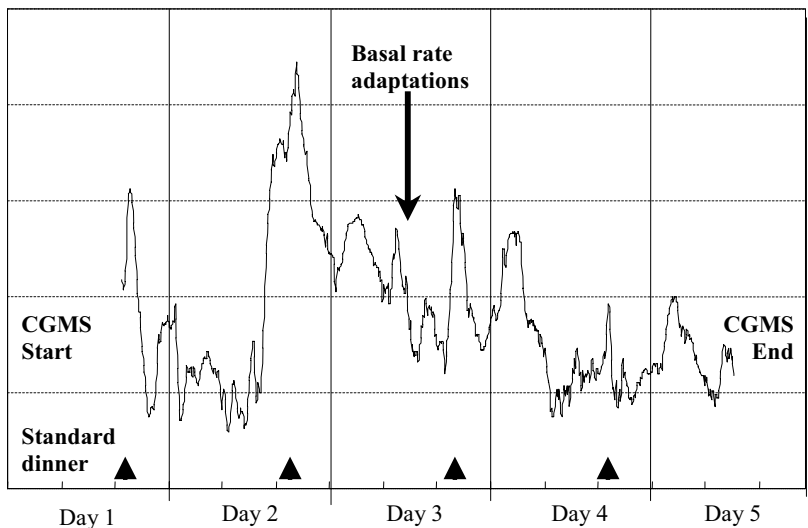

Fig. 1. Study design

Day 1:

a) Education of the tested person: on how to use the CGMS, how to keep to the study protocol (daily calibration of the sensor, alarms, frequency of SMPG at least five times a day, standard meals containing $60 \mathrm{~g}$ of carbohydrates between 18:00 and 19:00 hrs followed by overnight fasting up to breakfast between 8:00 and 9:00 hrs, usual meals and muscular exercise during the day, registration of prandial boluses, hypoglycaemias, combatting hypoglycaemia by means of $250 \mathrm{ml}$ of juice, and others) and how to record the important events in a diary and/or monitor ${ }^{12}$.

b) Checking the function of the monitor and connecting cable. c) Insertion of the sensor into the subcutaneous tissue of the abdomen about $5 \mathrm{~cm}$ from the umbilicus and at least $10 \mathrm{~cm}$ from the insertion of the insulin pump (Fig. 2).

d) Sensor initialization.

e) Following the successful initialization the tested person used the CGMS at home while maintaining his/her normal daily routine.

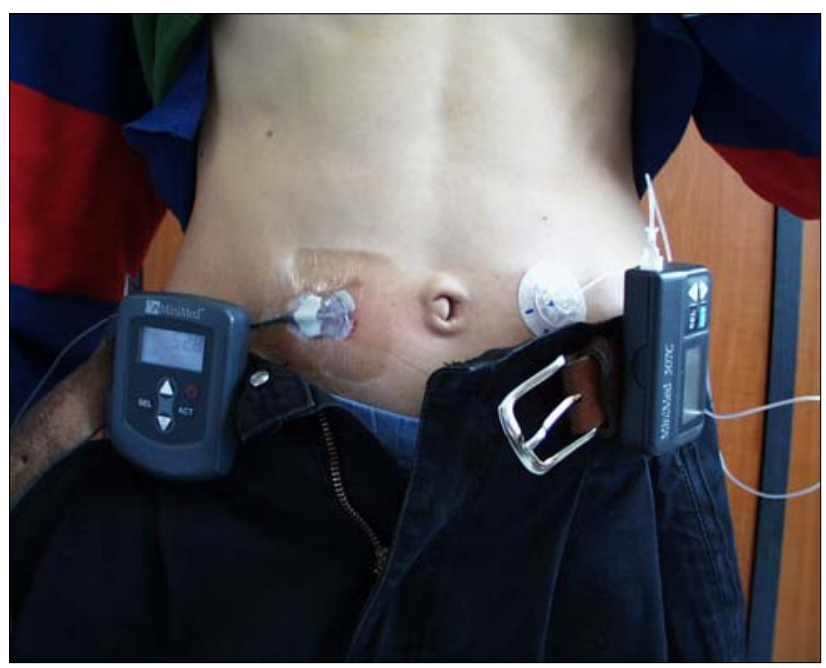

Fig. 2. Continuous Glucose Monitoring System (MinimedMedtronic): monitor, connecting cable, and sensor inserted into the subcutaneous tissue (right handside from the umbilicus) together with an insulin pump Minimed 507c with infusion set inserted into the subcutaneous tisue (left handside from the umbilicus) 
Table 2. Insulin doses (BR, PB), MPG (288 values/d) and carbohydrates in meals before (day 2) and after (day 4) adaptation of BR and PB. Persons 4 and 7 were excluded from calculations of means (stars). Decrease of values is marked (grey field) in evaluated persons only.

\begin{tabular}{|c|c|c|c|c|c|c|c|c|c|c|}
\hline \multirow{2}{*}{$\begin{array}{c}\text { Person } \\
\text { No. }\end{array}$} & \multicolumn{2}{|c|}{ BR [IU/d] } & \multicolumn{2}{|c|}{ PB [IU/d] } & \multicolumn{2}{|c|}{ BR + PB [IU/d] } & \multicolumn{2}{c|}{ MPG [mmol/l] } & \multicolumn{2}{c|}{$\begin{array}{c}\text { carbohydrates p.o. } \\
{[\mathrm{g} / \mathrm{d}]}\end{array}$} \\
\cline { 2 - 12 } & day 2 & day 4 & day 2 & day 4 & day 2 & day 4 & day 2 & day 4 & day 2 & day 4 \\
\hline 1 & 18.8 & 19.1 & 11.0 & 11.0 & 29.8 & 30.1 & 6.6 & $\mathbf{4 . 6}$ & 185 & 200 \\
\hline 2 & 34.5 & $\mathbf{3 3 . 7}$ & 14.5 & $\mathbf{1 4 . 0}$ & 49.0 & $\mathbf{4 7 . 7}$ & 8.0 & $\mathbf{6 . 7}$ & 167 & $\mathbf{1 4 2}$ \\
\hline 3 & 14.9 & 15.2 & 19.5 & 21.2 & 34.4 & 36.4 & 7.1 & $\mathbf{6 . 2}$ & 235 & 270 \\
\hline$* 4 *$ & $* 20.0 *$ & $* 20.6 *$ & $* 28.0 *$ & $* 16.0 *$ & $* 48.0 *$ & $* 36.6 *$ & $* 9.6 *$ & $* 4.8 *$ & $* 261 *$ & $* 220 *$ \\
\hline 5 & 12.9 & 16.8 & 24.5 & $\mathbf{1 8 . 0}$ & 37.4 & $\mathbf{3 4 . 8}$ & 10.3 & 11.8 & 180 & $\mathbf{1 7 0}$ \\
\hline 6 & 18.9 & 19.5 & 12.9 & $\mathbf{9 . 0}$ & 31.8 & $\mathbf{2 8 . 5}$ & 9.5 & 10.8 & 153 & 200 \\
\hline$* 7 *$ & $* 18.1 *$ & $* 17.7 *$ & $* 12.0 *$ & $* 13.5 *$ & $* 30.1 *$ & $* 31.2 *$ & $* 5.7 *$ & $* 6.0 *$ & $* 219 *$ & $* 246 *$ \\
\hline 8 & 17.0 & $\mathbf{1 6 . 7}$ & 11.5 & $\mathbf{1 0 . 5}$ & 28.5 & $\mathbf{2 6 . 7}$ & 5.3 & 7.3 & 218 & 220 \\
\hline 9 & 18.2 & $\mathbf{1 7 . 7}$ & 14.0 & $\mathbf{1 3 . 0}$ & 32.2 & $\mathbf{3 0 . 7}$ & 5.6 & $\mathbf{4 . 8}$ & 186 & 250 \\
\hline 10 & 18.6 & 18.9 & 15.0 & 15.0 & 33.6 & 33.9 & 9.8 & $\mathbf{7 . 3}$ & 195 & 230 \\
\hline mean & 19.2 & 19.7 & 15.4 & $\mathbf{1 4 . 0}$ & 34.6 & $\mathbf{3 3 . 6}$ & 7.8 & $\mathbf{7 . 4}$ & 190 & 210 \\
\hline SD & 6.1 & 5.5 & 4.2 & $\mathbf{3 . 8}$ & 6.0 & 6.1 & 1.8 & 2.4 & 25 & 39 \\
\hline
\end{tabular}

Table 3. Insulin doses (BR, PB), MPG (96 values/d) and carbohydrates in meals before (the night from day 2 till day 3 ) and after (the night from day 4 till day 5) adaptation of BR and PB. Persons 4 and 5 were excluded from calculations of means (stars). Decrease of values is marked (grey field) in evaluated persons only.

\begin{tabular}{|c|c|c|c|c|c|c|c|c|c|c|}
\hline \multirow{2}{*}{$\begin{array}{c}\text { Person } \\
\text { No. }\end{array}$} & \multicolumn{2}{|c|}{ BR [IU/d] } & \multicolumn{2}{c|}{ PB [IU/d] } & \multicolumn{2}{c|}{ BR + PB [IU/d] } & \multicolumn{2}{c|}{ MPG [mmol/l] } & \multicolumn{2}{c|}{$\begin{array}{c}\text { carbohydrates p.o. } \\
\text { [g/d] }\end{array}$} \\
\cline { 2 - 12 } & $\begin{array}{c}\text { night } \\
2 / 3\end{array}$ & $\begin{array}{c}\text { night } \\
4 / 5\end{array}$ & $\begin{array}{c}\text { night } \\
2 / 3\end{array}$ & $\begin{array}{c}\text { night } \\
4 / 5\end{array}$ & $\begin{array}{c}\text { night } \\
2 / 3\end{array}$ & $\begin{array}{c}\text { night } \\
4 / 5\end{array}$ & $\begin{array}{c}\text { night } \\
2 / 3\end{array}$ & $\begin{array}{c}\text { night } \\
4 / 5\end{array}$ & $\begin{array}{c}\text { night } \\
2 / 3\end{array}$ & $\begin{array}{c}\text { night } \\
4 / 5\end{array}$ \\
\hline 1 & 6.0 & 6.3 & 0.0 & 0.0 & 6.0 & 6.3 & 6.1 & $\mathbf{5 . 0}$ & 0 & 0 \\
\hline 2 & 6.5 & 6.5 & 0.0 & 0.0 & 6.5 & 6.5 & 10.2 & $\mathbf{8 . 5}$ & 0 & 0 \\
\hline 3 & 5.0 & 5.6 & 0.0 & 0.0 & 5.0 & 5.6 & 9.3 & $\mathbf{9 . 1}$ & 0 & 0 \\
\hline$* 4 *$ & $* 6.8 *$ & $* 6.8 *$ & $* 0.0 *$ & $* 0.0 *$ & $* 6.8 *$ & $* 6.8 *$ & $* 4.7 *$ & $* 2.5 *$ & $* 30 *$ & $* 25 *$ \\
\hline$* 5 *$ & $* 4.8 *$ & $* 5.6 *$ & $* 0.0 *$ & $* 1.0 *$ & $* 4.8 *$ & $* 6.6 *$ & $* 8.9 *$ & $* 8.9 *$ & $* 0 *$ & $* 0 *$ \\
\hline 6 & 5.7 & 5.8 & 0.0 & 0.0 & 5.7 & 5.8 & 16.1 & $\mathbf{1 4 . 6}$ & 0 & 0 \\
\hline 7 & 4.8 & 4.8 & 0.0 & 0.0 & 4.8 & 4.8 & 3.9 & 10.1 & 0 & 0 \\
\hline 8 & 4.8 & 4.8 & 0.0 & 0.0 & 4.8 & 4.8 & 8.8 & $\mathbf{6 . 9}$ & 13 & $\mathbf{0}$ \\
\hline 9 & 5.3 & $\mathbf{5 . 2}$ & 0.0 & 0.0 & 5.3 & $\mathbf{5 . 2}$ & 7.4 & 7.6 & 0 & 0 \\
\hline 10 & 5.6 & 5.8 & 0.0 & 0.0 & 5.6 & 5.8 & 13.2 & $\mathbf{7 . 1}$ & 0 & 0 \\
\hline mean & 5.5 & 5.6 & 0.0 & 0.0 & 5.5 & 5.6 & 9.4 & $\mathbf{8 . 6}$ & 1.6 & $\mathbf{0}$ \\
\hline SD & 0.57 & 0.59 & 0.0 & 0.0 & 0.57 & 0.59 & 3.6 & $\mathbf{2 . 7}$ & 4.3 & $\mathbf{0}$ \\
\hline
\end{tabular}

Day 3:

a) In about 48 hours after the sensor insertion the data were transferred from the monitor and from the insulin pump (Minimed only) into the computer (Figures 3-7).

b) According to the evaluation of the whole protocol (including glucose concentrations, BR, PB of the in- sulin pump and amount of ingested carbohydrates), the basal rates were modified (mostly in the range \pm $0.1 \mathrm{IU} / \mathrm{h}$, only if the PG concentration exceeded the target limits, i.e. fPG 4.0-6.0 $\mathrm{mmol} / 1$ and/or prae- and postprandial PG $6.0-10.0 \mathrm{mmol} / 1$ ) and/or adaptations of prandial boluses were recommended. 


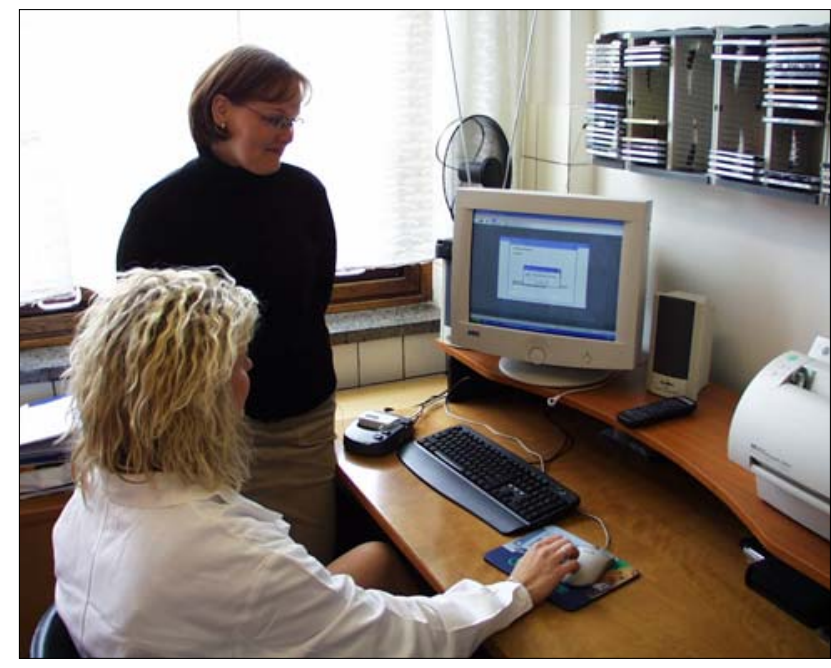

Fig. 3. Data transfer from the insulin pump Minimed 508 to the PC by means of Comstation and Minimed Solution Software

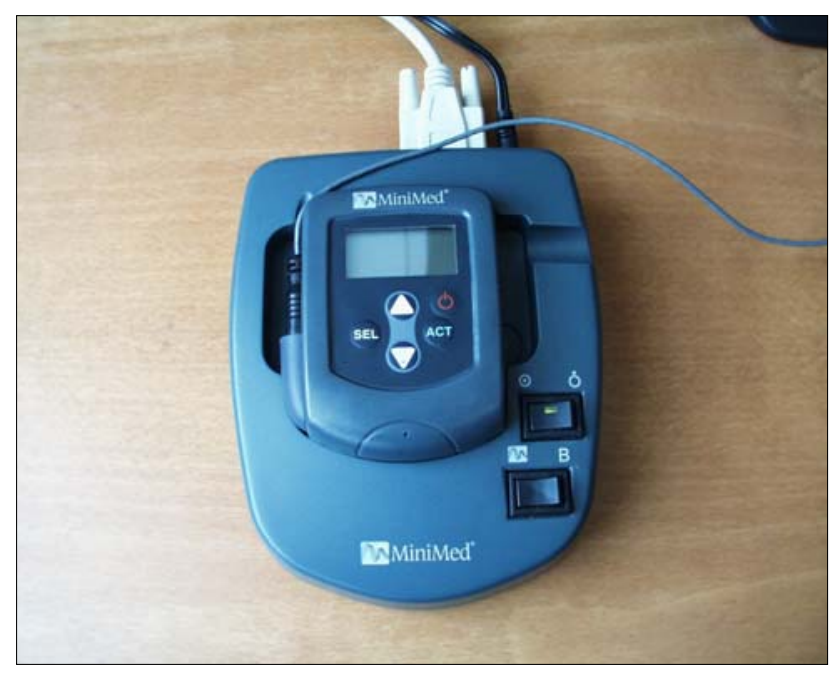

Fig. 4. CGMS Monitor and Comstation

Glucose Sensor Profile Modal Day

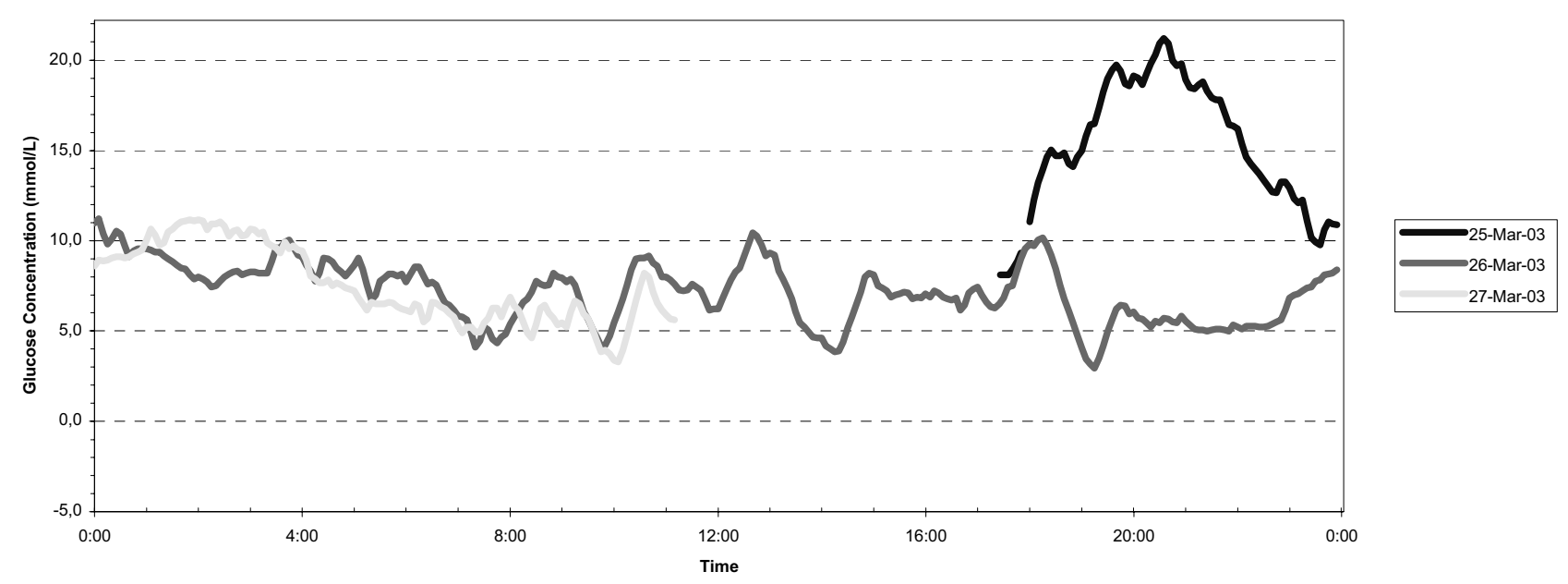

Fig. 5. Data downloaded from the CGMS-monitor into the PC and printed: Modal day - each day is drawn in different colour

c) Subsequently, the tested person continued in this adapted routine at home.

Day 5:

a) In about 96 hours after the sensor insertion the second (final) transfer of data from the CGMS monitor and from the insulin pump into the computer was performed. The correlation coefficient of the sensors and meter values never decreased below $90 \%$.

b) This second evaluation resulted in final individual recommendations for $\mathrm{BR}$ and/or $\mathrm{PB}$ (to be evaluated in the near future).

c) The sensor was removed.

\section{Evaluation of the results}

Comparisons of the obtained data (MPG, BR, PB and amount of carbohydrates in meals) were performed for the following periods of time:

1) Day 2 (00:00-24:00 hrs) versus day 4 (00:00-24:00 hrs).

2) The night from day 2 till day 3 (22:00-6:00 hrs) versus the night from day 4 till day 5 (22:00-6:00 hrs).

\section{RESULTS}

An overview of investigated parameters is shown in Table 2 and Table 3.

Adaptations of insulin pump basal rates and prandial boluses based on two-day period of evaluation by means of the CGMS resulted in a decrease of MPG: 


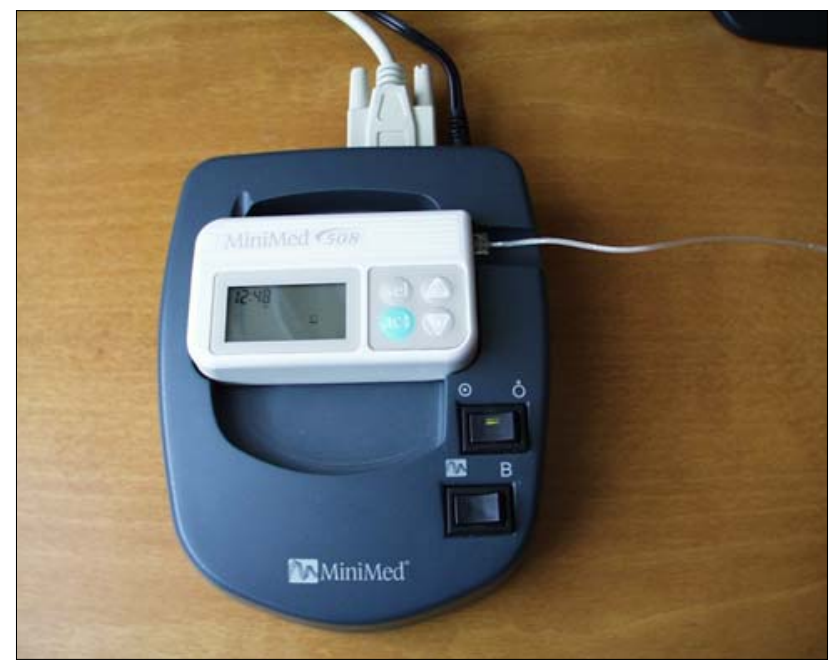

Fig. 6. Insulin pump Minimed 508 and Comstation ready to data transfer to the PC
1) when evaluating the 24-hour period in 5 out of 8 persons,

2) when evaluating the fasting night period (22:00 to 6:00 hrs) in 6 out of 8 persons.

An increase of MPG was found:

1) In 3 out of 8 persons during the assessment of the 24-hour period. This was probably related to the increased amount of ingested carbohydrates and/or to contraregulation after hypoglycaemia which occurred even though insulin doses had been decreased.

2) In 2 out of 8 persons during the assessment of the night fasting period while continuing the intake of the same insulin doses.

Excluded persons:

1) During the assessment of the 24-hour period persons 4 and 7 were excluded due to transient disconnection of the cable on day 4.

2) During the assessment of the night fasting person 4 was excluded due to prolonged hypoglycaemia. Person 5 was excluded due to disconnection of the cable on day 5 .

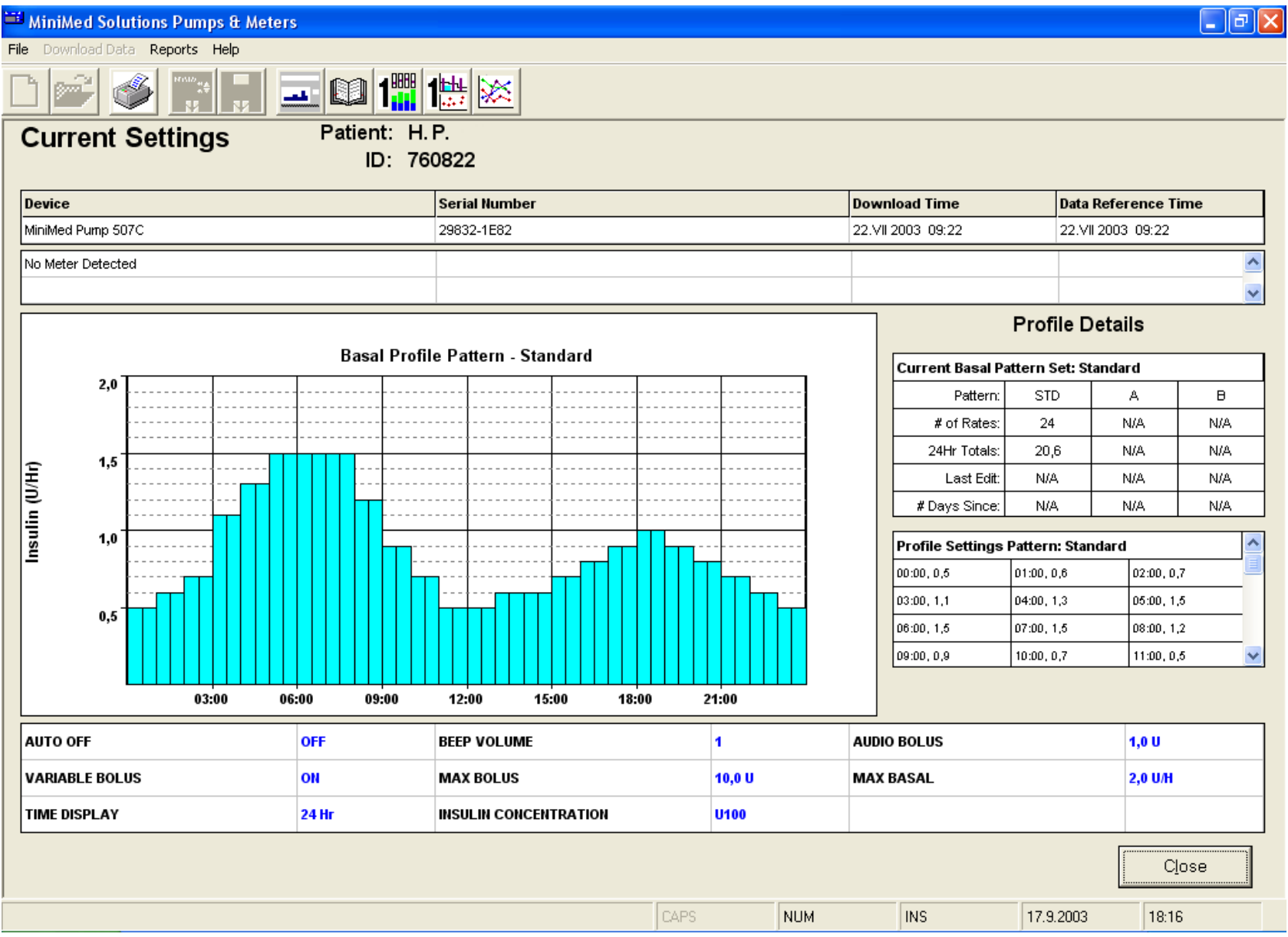

Fig. 7. Current settings of basal rates - data were downloaded from an insulin pump Minimed 508 into the PC by means of Minimed Solution Software and printed 


\section{DISCUSSION}

In the course of the last thirty years continuous attempts have been made to develop an external closedloop system to enable adequate substitution of insulin in persons with type 1 diabetes mellitus. There are few problems with insulin pumps and, on the other hand, quality and lifetime of the glucose sensor and appropriate algorithm for insulin administration are the limiting factors. For this reason, we have tried to use the present devices (CGMS and insulin pumps), PC with respective software and our own experience as a "fair means" to improve diabetes control.

The limited number of patients does not allow us to do a statistical analysis. However, the presented case reports yield important information for further studies.

\section{CONCLUSIONS}

The CGMS is a useful means for assessment of effectiveness of basal rate and prandial boluses in persons with type 1 diabetes melittus treated by means of an insulin pump. Using the CGMS with an adaptation BR and PB based on two-day PG measurement resulted in MPG decrease in 5 out of 8 persons when assessing the 24-hour period, and in 6 out of 8 persons when assessing the night fasting period. MPG increased in 3 out of 8 persons when assessing the 24-hour period, and in 2 out of 8 persons when assessing the night fasting period. In these persons a final correction of BR and PB was carried out. The effects will be monitored later on.

Further studies are necessary to adjust the algorithms for insulin substitution.

\section{ACKNOWLEDGEMENTS}

This study is supported by the research projects of the Ministry of Education, Czech Republic: MSM 151100005.

\section{REFERENCES}

1. Bode W, Hirsch B. (2000) Using the Continuous Glucose Monitoring System to Improve the Management of Type 1 Diabetes. Diabetes Technology \& Therapeutics 1, Suppl 1, 43-48.

2. Bode W. (2000) Clinical Utility of the Continuous Glucose Monitoring System. Diabetes Technology \& Therapeutics 1, Suppl 1, 35-41.

3. Brož J, Anděl M. (2002) Použití kontinuální monitorace glykémie u pacientů s diabetem mellitus 1 . typu léčených pomocí inzulínové pumpy snižuje počet symptomatických hypoglykemií. Diabet. Metabol. Endokrin. Výž. 5/1, 12.

4. Einhorn D, Sadler Ch, Fink RI. (2000) New insights on glycemic control in the ambulatory setting: MiniMed's continuous glucose monitoring system. Endo Society $82^{\text {nd }}$ Mtg, 424.

5. Gross TM, Bode BW, Einhorn D, Kayne DM, Reed JH, White NH, Mastrototaro JJ. (2000) Performance evaluation of the MiniMed continuous glucose monitoring system during patient home use. Diabetes Technology \& Therapeutics 2/1, 49-56.

6. Gross TM, Mastrototaro JJ. (2000) Efficacy and Reliability of the Continuous Glucose Monitoring System. Diabetes Technology \& Therapeutics 1, Suppl 1, 19-26.

7. Cheyne E, Kerr D. (2002) Making "sense" of diabetes: using a continuous glucose sensor in clinical practice. Diabetes/Metabolism Research Reviews 18, Suppl 1, 43-48.

8. Chlup R, Mlčák P, Boudová E, Bartek, J. (2003) Kontinuální měřní koncentrace glukosy v intersticiální tekutině - naše první zkušenosti (Continuous Glucose Monitoring in Interstitial Fluid - Initial Experience). Klin. Biochem. Metab. 10, 37-43.

9. Maran A, Crepaldi C, Tiengo A, Grassi G, Vitali E, Pagano G, Bistoni S, Calabrese G, Santeusanio F, Leonetti F, Ribaudo M, Di Mario U, Annuzzi G, Genovese S, Riccardi G, Previti M, Cucinotta D, Giorgino F, Bellomo A, Giorgino R, Poscia A, Varalli M. (2002) Continuous subcutaneous glucose monitoring in diabetic patients: a multicenter analysis. Diabetes Care 25/2, 347-352.

10. Mastrototaro JJ. (2000) The MiniMed Continuous Glucose Monitoring System. Diabetes Technology \& Therapeutics 1, Suppl 1, $13-18$.

11. Melki V, Hanaire-Broutin H. (2001) Indication of CGMS (Continuous Glucose Monitoring System) in the functional investigations of adult type 1 diabetic patients. Diabetes - \& Metabolism 27, 618-623.

12. Mlčák P, Chlup R, Boudová E, Bartek J, Zapletalová J. (2003) Vývoj koncentrace glukosy v intersticiální tekutině u nediabetiků s ohledem na detekci fenoménu svítání - pilotní studie (Assessment of Glucose Concentrations in Interstitial Fluid in Non-diabetic Subjects with Regard to detection of the Dawn Phenomenon - Pilot Study). Klin. Biochem. Metab. 10, 44-49.

13. Musil F, Šmahelová A, Kusalová M, Mottl R. (2002) Systém pro kontinuální monitorování glykémie a jeho využití v léčbě diabetu vybrané kazuistiky. Diabet. Metabol. Endokrin. Výž. 5/1, 36-38.

14. Rebrin K, Steil GM. (2000) Can interstitial glucose assessment replace blood glucose measurements? Diabetes Technology \& Therapeutics 2/3, 461-472.

15. Robert JJ. (2002) Continuous monitoring of blood glucose. Hormone Research 57, Suppl 1, 81-84. 